\title{
Implementation of the YII Framework-Based Job Training Assessment System
}

\author{
Dwi Andayani ${ }^{1}$, Nuke Puji Lestari Santoso ${ }^{2}$, Alfiah Khoirunisa ${ }^{3}$, Kelvin Pangaribuan $^{4}$ \\ 1,2,3,4 Universitas Raharja Jenderal Sudirman No.40, RT.002/RW.006, Cikokol, Kec. \\ Tangerang, Kota Tangerang, \\ Banten 15117 \\ e-mail: mailto:dwi.andayani@raharja.info ${ }^{1}$, nuke@raharja.info² ${ }^{2}$, alfiah@raharja.info ${ }^{3}$, \\ kelvin.pangaribuan@raharja.info
}

To cite this document :

D. Andayani, N. P. Lestari, A. Khoirunnisa, K. Pangaribuan "Implementation of the YII Framework-Based Job Training Assessment System," Aptisi Transactions on Management (ATM), vol. 5, no. 1, pp. 1-10, January 2021.

DOI :

https://doi.org/10.33050/atm.v5i1.1231

\begin{abstract}
The current significant progress has been experienced by the publication of Information media, one of which is the scoring system. In measuring the ability of students or students in learning outcomes during the learning process assessment system is very important in an educational institution both high school and college. Universitas Raharja is one of the educational institutions that have implemented the assessment system $(P E N+)$ online, which provides services to the lecturers of the University of Raharja in the input of the value that can be accessed anywhere and Anytime. However, nowadays for the process of the input of the value of work lecture (CTF) that has been run by students is still done manually or not computerized because lecturers still have to come to the campus to fill out a list of student value lists Submitted to the $R P U$. This is very inefficient, because in the assessment system PEN + lecturers have not been able to input the value of work lecture $(K K P)$ in real time. Therefore, there is a need for development in the Coursework Assessment System (CTF) where the value of the input form is Grade. In this study there were 10 (ten) literature studies on the assessment. Thus there are 2 (two) advantages that the lecturer does not need to come to the campus to fill the form that is then handed over to the RPU and notifications for a list of values that students receive will be faster.
\end{abstract}

Keywords: Publication Media, PEN + (Rating Plus), Value Input

\section{Introduction}

In the face of the world of competition that takes place very quickly, the existing information technology will undergo developments that suit the needs of the organization. In addition, in this era, competition is one of the keys to success in every College that is always required to be able to compete widely and globally [1]. However, universities should be able to provide and provide an efficient and fast service to students [2]. In its application must be equipped with facilities supporting the success rate of the objectives of the programs and services provided effectively [3]. Especially in terms of useful media to convey information, it is expected to make the system that has run better [4]. Including the assessment system is a very important part of the learning process of teaching [5].

Assessment is the benchmark of learners in measuring ability during the learning activities and is very much needed information by students and students in high school and 
college institutions [6]. The effective at Raharja University not only implements learning methods but also the orders of lecturers, and students are invited to pray, think and act [7] [8].

In addition Raharja University always strives to fulfill the need for information systems that can improve the academic performance process. One of the systems that is now not available is the work of coursework Assessment (CTF). The process of assessment and input of value at Raharja University for practical Work Lecture (CTF) is still done manually and has not been computerized, because lecturers still have to come to the campus to perform assessments on a form that must be Must be submitted to lecture and exam (RPU) registration. And the RPU party must also input the value into the computer, if the value is already out the student must come to the campus to see the value. It is very ineffective and efficient because it will waste time and cost just to come to campus. This kind of process should be done in a more convenient and practical way if there is a system for the assessment of Practice work (CTF) and the delivery of information online [9].

The development of technological currents causes the delivery of information over time to always change, impacting the recipient of the information [10]. It is very important in communication because there is a data set that must be passed on both to each individual and to several individuals directly [11]. In the running of the process of sending good and effective information is determined by the system and model used [12]. In order for a good assessment of the modern way must be applied to change the ineffective, so that there is a medium to input grades and convey information to students quickly and accurately. There needs to be a system update where lecturers can input value online through a website, to facilitate and efficiency lecturers access anywhere and anytime [13]. Through improvements in the conventional assessment process system will be changed to online so that input of the grades of Practical Work Lecture (KKP) students can be easily done by lecturers. And students will be quicker to receive grade list information without having to come to campus.

\section{Research Method}

The research phase process can be seen in figure 1

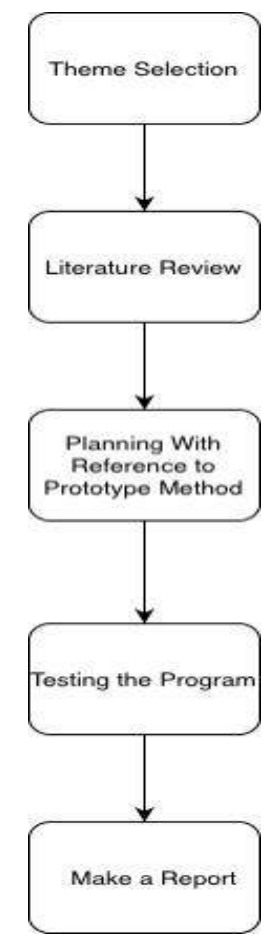

Figure 1. Research Stage 
Description :

At Point no 1 which is to determine the problem, then choose the theme to be taken, namely Input Grade KKP PEN +. At Point no 2, the Literature Review, is used to look for references in the PEN + system, read and understand from various sources such as journals and books. At Point no 3, which is using a system design method that can be adjusted to the problem and the program created is prototyping. At Point no 4 namely Testing the program, this stage is carried out for the validity and reliability of the program that has been made. At Point no 5, namely Make a report in the form of online documents.

\subsection{Literature Review}

In this study there are 10 literature studies as follows : Research conducted by Untung Rahardja, Qurotul Aini, Vivid Kristiani Alfad Zebua Year 2019 with the title "Application of KKPBased KKP Worthy Student Checking System at Higher Education". This research discusses how the system can know students who can be sure to participate in job training examined through the Head of Department [14]. Research that has been made by Rick Thio Nanda, Ina Namora in 2020 with the title "Influence on Work Communication, Leadership and Job Training on Employee Job Satisfaction in PT. Bumisari Prima Medan". Research that discusses the analysis of work communication, leadership and employee job training on job satisfaction at PT Bumisari Prima [15].

This research was conducted by Diah Aryani, Qurotul Aini, Fernanda Setyobudi Armansyah in 2017 with the title "Designing Android Package Mobile Web On Assessment System In Higher Education". Discussing the android package-based assessment system to make it more accessible to lecturers through a smartphone [16]. The research has been conducted by Veronica Sherly Agustina Year 2020 with the title "Competency Model Development and Design of Competency-Based Employee Performance Assessment Information System at PT. Sucaco, Tbk". This research on competency-based employee performance assessment information systems will be able to assist the company in placing competent human resources for a particular position [17].

Research conducted by Subandi, Basuki Hari Prasetyo, Dian Anubhakti in 2020 with the title "Application Assessment of Performance And Work Behavior of Employees of Budi Luhur University based on web". This research discusses the design of an effective and efficient HR system, towards the assessment of employee performance that is targeted, fair, objective and impactful to improve the work motivation and productivity of employees in the environment of Budi Luhur University Jakarta [18]. The research has been conducted by M. Kadafi, Irman Effendy in 2020 with the title "Designing Employee Performance Assessment System with 360-Degree Method". Research that discusses designing computerized employee performance assessment systems to perform web-based assessments using the PHP programming language (Hypertext Preprocessor) [19].

This research was conducted by Dimas Haryanto in 2019 with the title "Evaluation Using Benchmarking Procedures and Practice Assessment Guidelines at the Faculty of Science and Technology UIN Riau Sanctuary". Discussing the evaluation of fieldwork performance in the Faculty of Science and Technology Using benchmarking methods, comparisons were made between case studies and other sources [20]. Research conducted by H. Dadang Suparman in 2020 under the title "Effect of Performance Assessment and Employee Training on Job Placement on PT. Sinar Effendi Murni Sukabumi City". Discussing determining the performance assessment effect and training of employees working placement in PT. Pure Effendi Rays [21].

The research was conducted by Siti Nurmiati in 2020 under the title "Designing Performance Assessment of Web-Based Employees With Rating Scale Method". This research discusses the design of applications in implementing employee performance assessments that also take into account other factors of employee work that later than the assessment results will be used to provide awards and sanctions based on Government Regulation 46 of 2011 by applying assessments divided into two aspects including SKP (Employee Work Target) and PKP (Employee Performance Assessment) [22]. The research has been conducted by Ferry Susanto, Nantia Marisa in 2020 with the title "Supporting System of Employee Performance Assessment Decisions With Simple Additive Weighting Method". This research discusses the design of a decision support system using saw (Simple Additive Weighting) method, to facilitate the process

Implementation of the YII Framework-Based Job Training Assessment System (Dwi Andayani) 
of objectively assessing employee performance in LPM based on the weights and assessment criteria that have been determined [23].

\section{Results and Analysis 3.1 Problem}

In supporting the development and progress of the lecture world, Raharja University has made many innovations in the field of science and technology. But in the process there are still many constraints in the activity of input value that later must be found troubleshooting to be able to solve the problem. In the process of input of grades is very important at raharja University, because the input process must be filled out the assessment form of practical work lecture (KKP) first then a new assessment can be done. This is very ineffective, because lecturers have to come to campus to fill out a form that will then be given to RPU for the process and have to wait a long time, After finishing students have to come to campus to see the list of grades. Here is an analysis of the problems to convey kkp results to students :

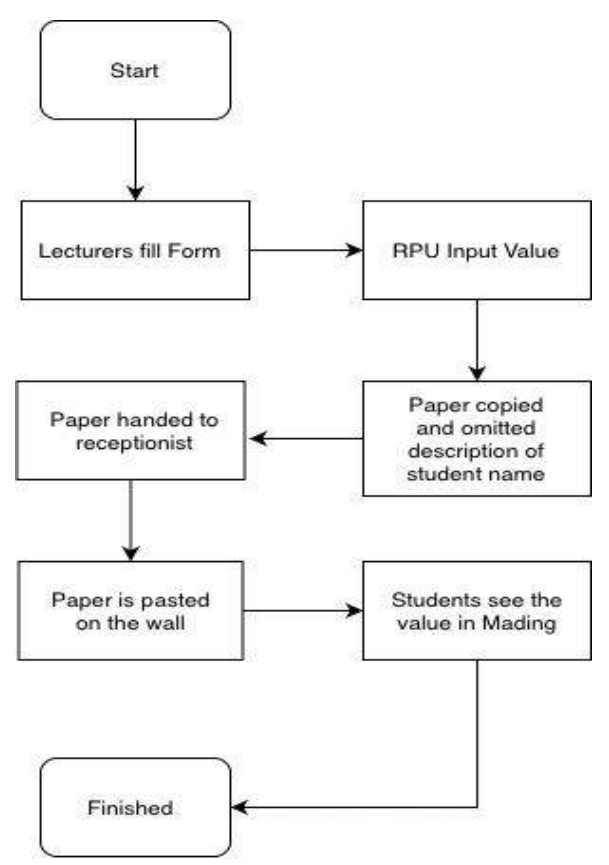

Figure 2. Problem analysis

a. The first is, lecturers check in advance and assess the results of the student KKP, after the lecturer has finished examining and assessing the results of the student KKP then the lecturer fill out the assessment form KKP that has been provided by the RPU then deliver the form The registration of lectures and exams (RPU).

b. The second is, that after RPU receives the KKP assessment form from the lecturer, rpu's task inputs the value of the form into the computer.

c. The third, when finished input will be printed, then all sheets are given to the head of the major for copy. However, in this process the student's name will be omitted because the name is not recommended to be displayed on the wall magazine, this process takes a long time and costs so it is not effective and efficient.

d. The fourth stage is, the copy paper will then be given to the receptionist.

e. The fifth stage is, the receptionist will attach the copy paper to the number of student KKP very much to each wall magazine in the University of Raharja.

f. The last stage is, students need to come to campus to see their value in the magazine wall and should be queued, this process is really time consuming and cost for students.

\section{2 problem solving}


In order to address the problems described above, there is a need for development in the assessment and input system so that the process of the input value can be done online, so as to facilitate the performance of lecturers and students Easily obtain the value result information. PEN + is used in the means of input and delivery of information about the student's value. Here is the program listing :

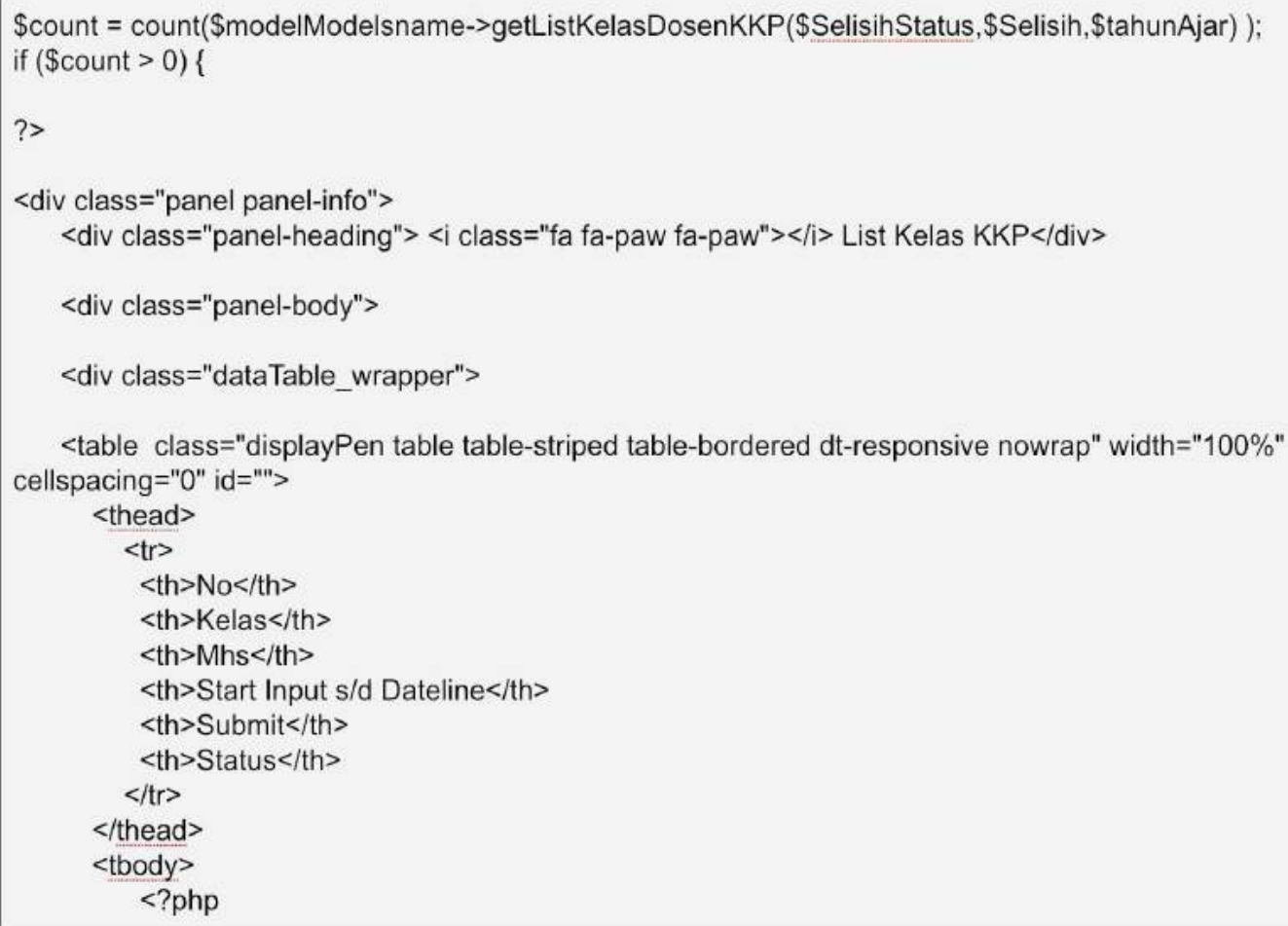

Figure 3. Process of input value

The picture above is a listing program for lecturers to process the input grade KKP.

\subsection{Research Implementation}

\subsubsection{Front End Pen + display}




\section{WELCOME TO THE MAGICAL}

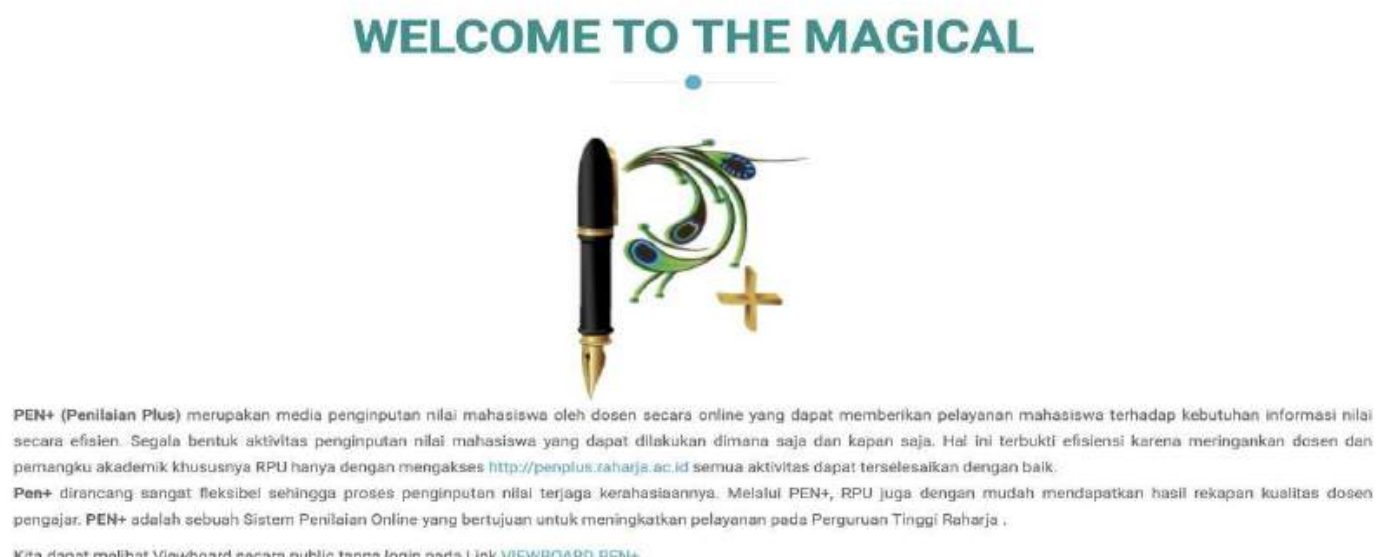

Figure 4. Main Menu When lecturers access the Pen + website http://penplus.raharia.ac.id/

3.3.2 KKP Menu Display

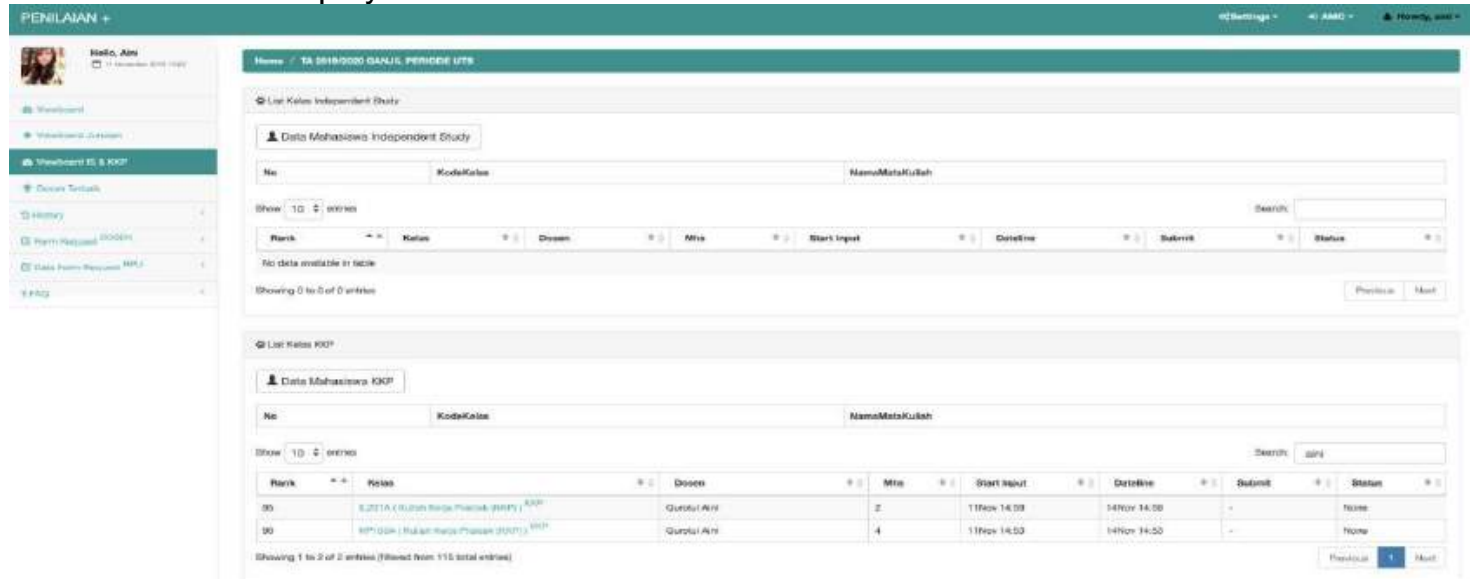

Figure 5. KKP Menu Display

In this view there is a list of classes KKP that can be done by lecturers

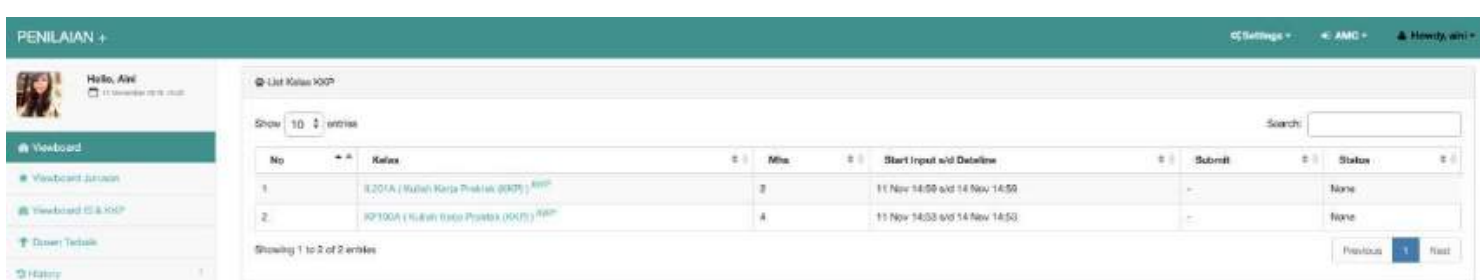

Figure 6. KKP Class List view

3.3.3 Input Grade KKP 


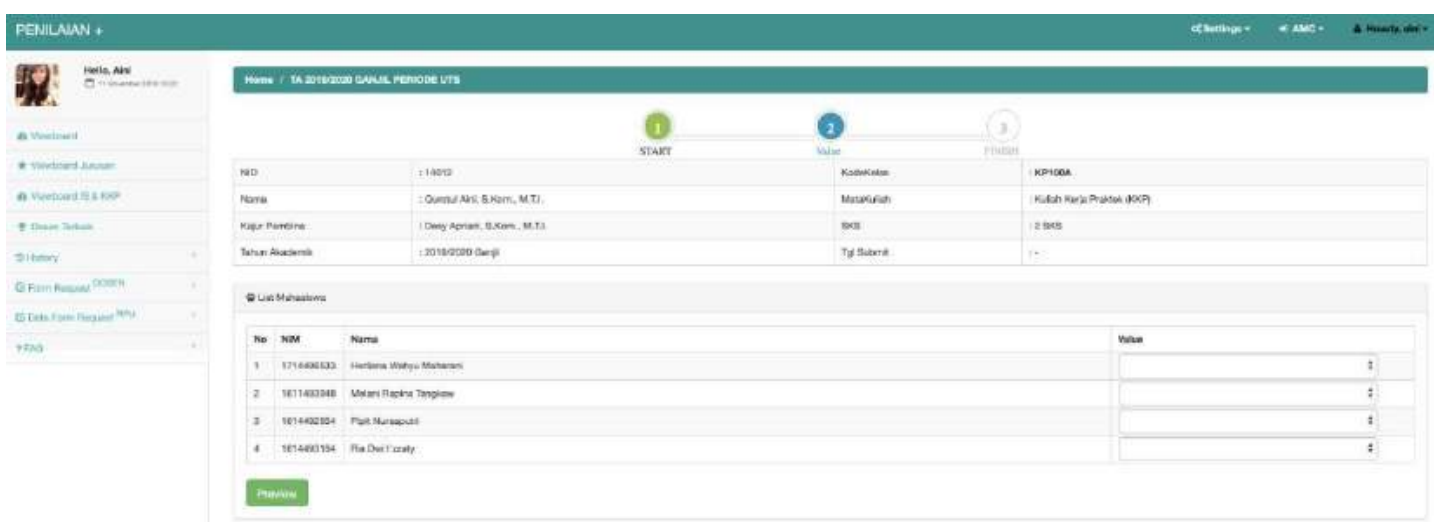

Figure 7. Display before input grade

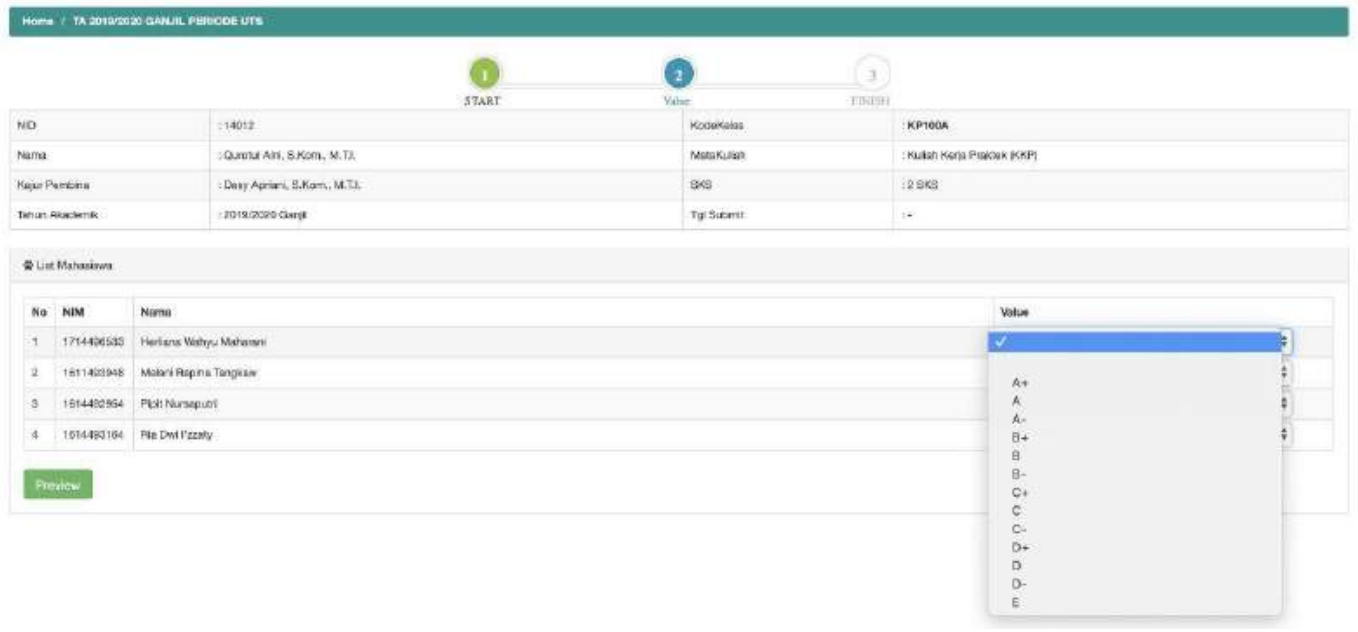

Figure 8. Display when input grade

In this view the value or value provided is only a grade

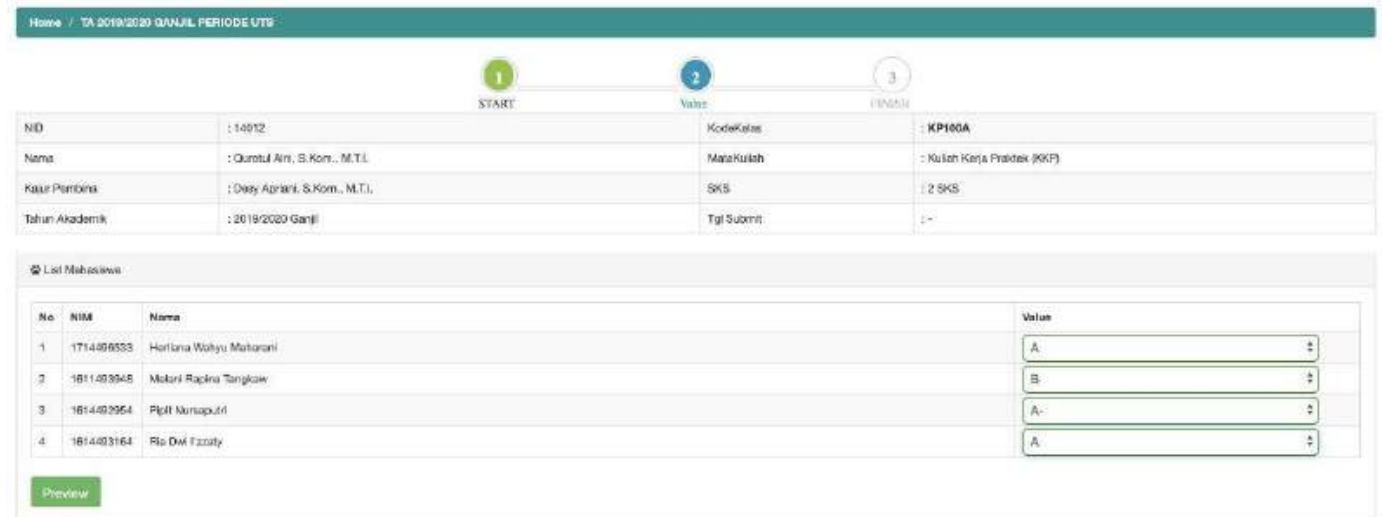

Figure 9. Value Provided only a Grade 


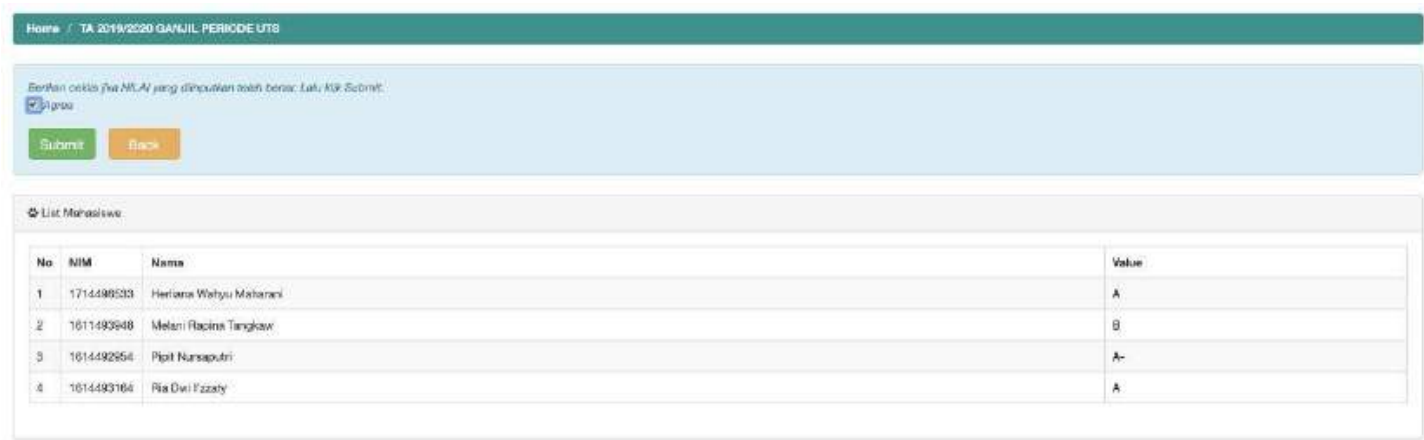

Figure 10. Display when grade is given

3.3.4 KKP Input Grade Results

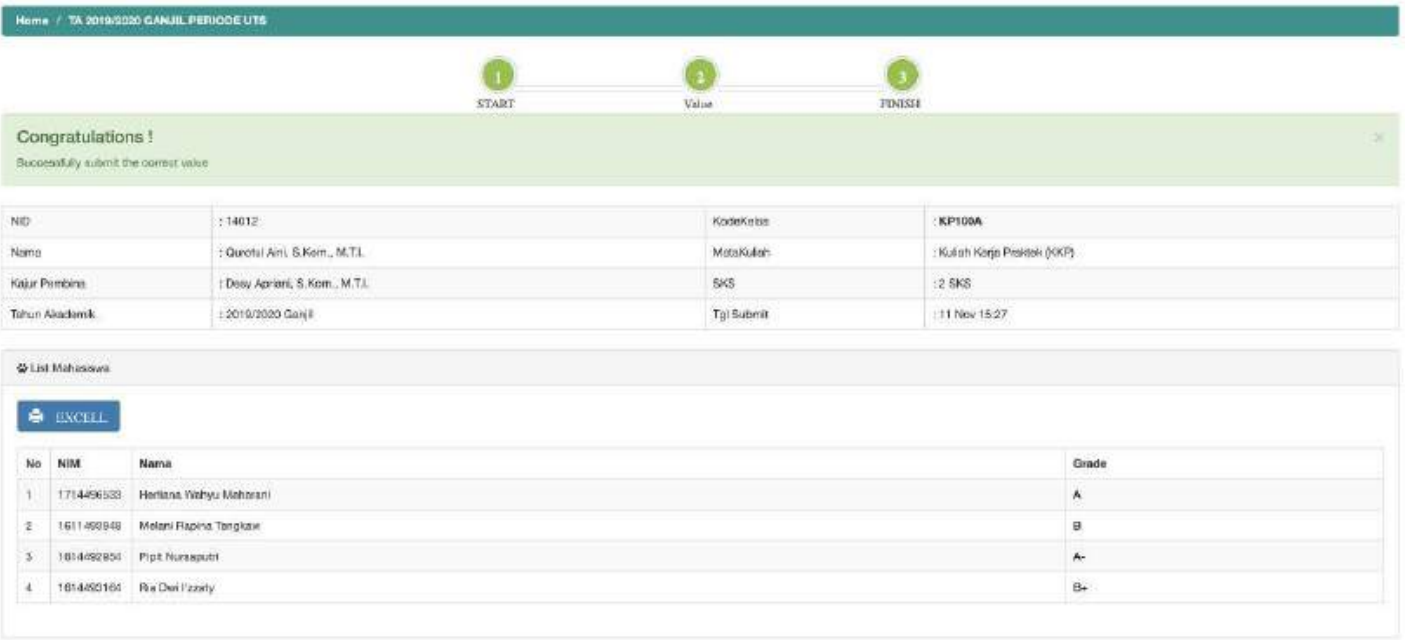

Figure 10. Input Grade KKP Final result

\section{Conclusion}

Based on what has been explained above can be concluded that with the system Input grade KKP in PEN + (assessment Plus) is a :

a. Effective system in providing facilities for lecturers when the process of input value in the form of KKP assessment becomes easier and more efficient.

b. Lecturers do not need to fill the assessment form and can reduce paper usage.

c. Students don't have to come to campus just to see their KKP grades in the magazine wall.

d. The process of delivering assessments is faster and online

\section{References}

[1] N. K. S. Astini, "Pemanfaatan Teknologi Informasi dalam Pembelajaran Tingkat Sekolah Dasar pada Masa Pandemi Covid-19," LAMPUHYANG, vol. 11, no. 2, pp. 13-25, 2020.

[2] F. Santoso, "ANALISIS MEDIASI PRESTASI BELAJAR PADA PENGARUH KUALITAS LAYANAN TERHADAP KEPUASAN MAHASISWA (STUDI PADA MAHASISWA UNIVERSITAS ISLAM MALANG).," JIMMU (Jurnal Ilmu Manajemen), vol. 5, no. 1, pp. 31-48, 2020.

[3] A. Y. Labolo, "SISTEM PENDUKUNG KEPUTUSAN PENILAIAN KINERJA DOSEN DENGAN MENGGUNAKAN METODE ADDITIVE RATIO ASSESSMENT (ARAS)," 
Simtek: Jurnal Sistem Informasi dan Teknik Komputer, vol. 5, no. 1, pp. 31-35, 2020.

[4] U. Rahardja, Q. Aini, D. Apriani, and A. Khoirunisa, "Optimalisasi Informasi Manajemen Laporan Assignment Pada Website Berbasis Content Management System," Technomedia Journal, vol. 3, no. 2, pp. 213-223, 2019.

[5] A. Purwanto, R. Pramono, M. Asbari, C. C. Hyun, L. M. Wijayanti, and R. S. Putri, "Studi Eksploratif Dampak Pandemi COVID-19 Terhadap Proses Pembelajaran Online di Sekolah Dasar," EduPsyCouns: Journal of Education, Psychology and Counseling, vol. 2, no. 1, pp. 1-12, 2020.

[6] U. Rahardja, Q. Aini, and N. Enay, "Optimalisasi Dashboard pada Sistem Penilaian Sebagai Media Informasi di Perguruan Tinggi," Sisfotenika, vol. 7, no. 2, pp. 167176, 2017.

[7] H. Qudsyi, L. Indriaty, Y. Herawaty, I. Khaliq, and J. Setiawan, "Pengaruh metode pembelajaran kooperatif (cooperative learning) dan motivasi belajar terhadap prestasi belajar siswa SMA," Proyeksi: Jurnal Psikologi, vol. 6, no. 2, pp. 34-49, 2020.

[8] M. Yamin and S. Syahrir, "Pembangunan Pendidikan Merdeka Belajar (Telaah Metode Pembelajaran)," Jurnal Ilmiah Mandala Education, vol. 6, no. 1, 2020.

[9] Y. Yonvitner, M. Boer, and R. Kurnia, "Kajian tingkat efektifitas perikanan untuk pengembangan secara berkelanjutan di Provinsi Banten," Jurnal Kebijakan Perikanan Indonesia, vol. 12, no. 1, pp. 35-46, 2020.

[10] Q. Aini, U. Rahardja, R. Supriyati, and A. Khoirunisa, "Pengaruh Mailing Groups Sebagai Media Diskusi Dalam Motivasi Belajar Mahasiswa," JURNAL MEDIA INFORMATIKA BUDIDARMA, vol. 3, no. 1, pp. 24-29, 2019.

[11] C. Riswanti, S. Halimah, I. Magdalena, and T. S. Silaban, "Perbedaan Individu dalam Lingkup Pendidikan," PANDAWA, vol. 2, no. 1, pp. 97-108, 2020.

[12] N. Nurmalasari and Y. Rohayani, "Penerapan Metode Waterfall Dalam Perancangan Sistem Informasi Akuntansi Pengiriman Barang," JUSTIAN-Jurnal Sistem Informasi Akuntansi, vol. 1, no. 1, 2020.

[13] U. Rahardja, Q. Aini, and F. Faradilla, "Implementasi Viewboard Berbasis Interaktif Javascript Charts Pada Sistem Penilaian Perkuliahan," Jurnal IImiah Teknologi Informasi Asia, vol. 12, no. 2, pp. 91-102, 2018.

[14] U. Rahardja, Q. Aini, and V. K. A. Zebua, "Penerapan Sistem Pengecekan Mahasiswa Layak KKP Berbasis YII Framework Pada Perguruan Tinggi," Jurnal Teknoinfo, vol. 13, no. 2, pp. 96-99, 2019.

[15] R. T. Nanda and I. Namora, "PENGARUH KOMUNIKASI KERJA, KEPEMIMPINAN DAN PELATIHAN KERJA TERHADAP KEPUASAN KERJA KARYAWAN PADA PT BUMISARI PRIMA MEDAN," Jurnal Bisnis dan Manajemen, vol. 7, no. 1, 2020.

[16] D. Aryani, Q. Aini, and F. S. Armansyah, "Perancangan Android Package Mobile Web pada Sistem Penilaian di Perguruan Tinggi," Sisfotenika, vol. 7, no. 2, pp. 155166, 2017.

[17] V. S. Agustina, "Pengembangan Model Kompetensi dan Perancangan Sistem Informasi Penilaian Kinerja Karyawan Berbasis Kompetensi Pada PT. Sucaco, Tbk.," 2020.

[18] S. Subandi, B. H. Prasetyo, and D. Anubhakti, "Aplikasi Penilaian Kinerja Dan Perilaku Kerja Karyawan Universitas Budi Luhur Berbasis Web," Budi Luhur Information Technology, vol. 17, no. 1, pp. 46-52, 2020. 
[19] M. Kadafi and I. Effendy, "Perancangan Sistem Penilaian Kinerja Karyawan dengan Metode 360-Degree," in Bina Darma Conference on Computer Science (BDCCS), 2020, vol. 2, no. 1, pp. 121-128.

[20] D. Sebagai and S. Satu, "EVALUASI MENGGUNAKAN BENCHMARKING PROSEDUR DAN PEDOMAN PENILAIAN KERJA PRAKTEK DI FAKULTAS SAINS DAN TEKNOLOGI UIN SUSKA RIAU TUGAS AKHIR."

[21] H. D. Suparman and M. M. S Pd I, "PENGARUH PENILAIAN KINERJA DAN PELATIHAN KARYAWAN TERHADAP PENEMPATAN KERJA PADA PT. SINAR EFFENDI MURNI KOTA SUKABUMI," Jurnal Ekonomedia, vol. 9, no. 01, pp. 1-14, 2020.

[22] S. Nurmiati, "PERANCANGAN PENILAIAN KINERJA PEGAWAI BERBASIS WEB DENGAN METODE RATING SCALE," JURNAL REKAYASA INFORMASI, vol. 9, no. 1, pp. 1-5, 2020.

[23] Z. Mustofa, A. A. Kuncoro, and R. A. Prasetyo, "SISTEM PENDUKUNG KEPUTUSAN PENILAIAN KINERJA KARYAWAN DENGAN METODE ANALYTIC HIERARCHY PROCESS (AHP)," Elkom: Jurnal Elektronika dan Komputer, vol. 13, no. 1, pp. 116120, 2020. 